\title{
Nogomet kao sredstvo nacionalne identifikacije Hrvata \\ u Kraljevini SHS-u/Jugoslaviji i socijalističkoj Jugoslaviji
}

\author{
DAVOR KOVAČIĆ* \\ - https://doi.org/10.31823/d.28.4.5 • \\ UDK: 796.332:32(497.1) • Prethodno priopćenje \\ Primljeno: 23. studenoga 2019. • Prihvaćeno: 2. prosinca 2020.
}

${ }^{*}$ Dr. sc. Davor Kovačić,

Hrvatski institut za povijest u Zagrebu, Opatička ulica 10, 10000 Zagreb, Hrvatska, dkovacic@isp.hr

Sažetak: Pogrješno je razmišljanje da je nogomet samo tjelesno kretanje, grubo natjeravanje suparnika, jer je on često više od igre. Nogomet je suvremeni socijalni fenomen i stanje u nogometu često je pokazatelj stanja u društvu i politici. Na hrvatskim $i$ općenito južnoslavenskim prostorima nogomet je od samoga početka bio najpopularniji sport i privlačio je najveći broj gledatelja te izazivao veliko zanimanje javnosti. Nogomet nikada nije samo nogomet, uvijek je politiziran $i$ kroz njega se zrcale odnosi u društvu uopće te je na neki način rendgen svega onoga što se u društvu događa. U članku je prikazano kako je nogomet u Kraljevini SHS-u/Jugoslaviji i u socijalistickoj Jugoslaviji bio sredstvo za izražavanje hrvatskoga etničkoga i nacionalnoga identiteta uslijed političkih sporova i podjela.

Ključne riječi: Hrvati, Srbi, Hrvatska, Jugoslavija, politika, nogomet, nogometni klubovi.

\section{Uvod}

Najstariji zabilježeni početci igranja nogometa na hrvatskim i općenito južnoslavenskim prostorima sežu u drugu polovicu 19 stoljeća. Engleski inženjer Robert Whitehead 1856. stigao je u Rijeku prihvativši posao tehničkog upravitelja poduzeća Stabilimento tecnico fiumano STF (Riječki tehnički zavod). U tvornici je je radilo nekoliko engleskih inženjera i tehničara koji su u slobodno vrijeme igrali kriket, tenis i nogomet. Engleski inženjeri i tehničari bili su angažirani i na izgradnji željezničke pruge Rije- 
ka-Karlovac-Budimpešta. U listopadu 1873. prilikom puštanja u promet dionice Rijeka-Karlovac odigrana je prva nogometna utakmica u kojoj su igrali inženjeri i tehničari angažirani od strane mađarskih željeznica te inženjeri i tehničko osoblje zaposleno u tvornici torpeda. U igru su bili uključeni i radnici Riječani koji su činili jezgru Whiteheadove tvornice torpedo.

Nešto kasnije, oko 1880. u slavonskom gradiću Županji engleski vlasnici tvornice tanina prikazali su »neku neozbiljnu « igru loptom u kratkim hlačicama. U neposrednoj blizini tvornice i upravno-stambene zgrade bilo je izravnano travnato igralište za igranje loptom koju su Englezi donijeli sa sobom. Domicilno šokačko stanovništvo u Županji tada je govorilo: »Čudni su ljudi ti Englezi. Odrasli, a igraju se loptom«.

\section{Početci nogometa u Hrvatskoj i osnivanje prvih klubova kao izraz nacionalne svijesti}

Nogomet se u Hrvatskoj pojavio za vrijeme Austro-Ugarske Monarhije krajem 19. stoljeća i počeo se razvijati početkom 20. stoljeća. Istodobno s pojavom nogometa jačala je nacionalna svijest kod mnogih naroda unutar Austro-Ugarske Monarhije, pa tako i u Hrvata. U takvom društvenom i političkom ozračju dolazilo je i do osnivanja nogometnih klubova u Hrvatskoj. ${ }^{1} \mathrm{U}$ travnju 1911. godine u Zagrebu u restoranu Nova pivana u Draškovićevoj ulici govorilo se o $\gg$ osnutku kluba građana našeg grada «. Međutim tada je pokrenuto i pitanje osnutka mađarskoga nogometnoga kluba u Zagrebu, što je izazvalo negodovanje većine nazočnih. Nezadovoljstvo je još više dolazilo do izražaja jer se govorilo da taj mađarski klub već ima sastavljenu upravu koja je počela nagovarati istaknute igrače tadašnjih zagrebačkih klubova HASSKK-a i Concordie da uz dobra namještenja na željeznici prijeđu u novi klub. ${ }^{2}$ Naime u Ugarskom saboru donesen je 1907. zakon pod imenom Željezničarska pragmatika prema kojem se trebala ozakoniti i provesti mađarizacija na željeznicama u Hrvatskoj i Slavoniji. Na svim željezničkim postajama u Hrvatskoj stavljeni su nazivi gradova i mjesta na mađarskom jeziku. U takvom ozračju vijest o osnivanju mađarskoga nogometnoga kluba u Zagrebu izazvala je otpor među građanima. Poslije završetka sastanka većina je nazočnih u povorci uz pjevanje rodoljubnih hrvatskih pjesama i povike protiv mađarizacije Hrvatske i osnivanja mađarskoga nogometnoga kluba došla ispred zgrade Prometne uprave državnih željeznica u Mihanovićevoj ulici. Putem su se demonstrantima priključili i brojni građani koji su razbili gotovo sve prozore na toj zgradi. Odmah je stigla i policija koja je brutalno postupila s demonstrantima i većinu ih je uhitila i odvela u zatvor. Poslije je na osnivačku skupštinu mađarskoga kluba došlo više Hrvata nego Mađara i njihovih

\footnotetext{
${ }^{1}$ D. KOVAČIĆ, Hrvatski nogomet u doba cara, kralja, poglavnika i maršala, Zagreb, 2019., 23-24.

${ }^{2}$ Isto.
} 
pristalica. Skupština je na kraju završila pjevanjem hrvatske himne. Kao reakcija na mogućnost osnivanja mađarskoga nogometnoga kluba, 26. travnja 1911. godine osnovan je I. hrvatski građanski športski klub, odnosno Građanski. ${ }^{3}$

U Splitu je 1911. godine osnovan NK Hajduk, a ime splitskom klubu nadjenuo je gimnazijski profesor Josip Barač nakon što su u njegov gimnazijski kabinet nahrupili praški studenti s namjerom da im predloži ime naglašene nacionalne orijentacije. Iznenađeni profesor Barač rekao je da su mu u kabinet upali kao hajduci i da bi to bilo najprikladnije ime za budući nogometni klub. Osnivači Hajduka odlučili su se za to ime koje je imalo i političko značenje, naime u Dalmaciji se početkom 20. stoljeća vodila borba između autonomaša, odnosno tolomaša koji su zapravo bili talijanaši i koje je podupirala Austrija te narodnjaka koji su bili protivnici Austro-Ugarske. Tolomaši su imali potporu državne administracije, tako je primjerice njihov klub odmah dobio odobrenje za registraciju, dok je Hajdukova molba uporno odbijana. Ipak, 13. veljače 1911. godine odobreni su Hajduku registracija i prva društvena pravila. ${ }^{4}$

Jedan od osnivača Hajduka, Vjekoslav Ivanišević izradio je prvu klupsku značku, grb i zastavu, što nije bilo po volji ondašnjim austrijskim vlastima. Naime vjerojatno se na odobrenje austrijskih vlasti tako dugo čekalo jer su značka i zastava imale simbole hrvatskoga grba i zastave te su austrijske vlasti u Hajduku vidjele još jedno novo mjesto gdje će se okupljati protivnici Monarhije. ${ }^{5}$

Prva nogometna utakmica između Hrvata i Srba odigrana je 11. lipnja 1911. godine u Zagrebu između HAŠK-a i reprezentacije Kraljevine Srbije. Zagrebački klub pobijedio je u prvoj utakmici rezultatom $8: 0$, a u drugoj rezultatom $6: 0$. Reprezentacija Srbije bila je sastavljena od igrača iz kluba Srpski mač, koji je osnovan 1906. godine kao Loptački odsjek pri istoimenom mačevalačkom društvu. Igrači toga kluba zakazali su utakmicu sa zagrebačkim HAŠK-om, iako je predsjednik kluba smatrao da Srpski mač nije dorastao protivnik tada već afirmiranom zagrebačkom klubu i da se ne treba sramotiti na utakmicama u Zagrebu. Zbog toga su igrači prije putovanja u Zagreb istupili iz matičnoga kluba i samovoljno nastupili kao reprezentacija Kraljevine Srbije. Poslije povratka srpski su nogometaši u beogradskom tisku dočekani na nož, pa su igrači koji su istupili iz Srpskoga mača osnovali 6. srpnja 1911. godine novi klub Beogradski Sport Klub (BSK). ${ }^{6}$

${ }^{3}$ Z. MAGDIĆ, Legende zagrebačkog nogometa, Zagreb, 1996., 21.

${ }^{4}$ M. GARBER, Hajduk u sto i jednoj priči, Stobreč, 2011., 20-21.

${ }^{5}$ Isto, 25. Zbog svojih političkih nazora i hrvatskoga domoljublja jednako kao austrijskim Ivanišević nije bio podoban ni kasnijim jugoslavenskim režimima. Poslije Drugoga svjetskoga rata nove komunističke vlasti zatvarale su ga i potisnule iz javnoga života.

${ }^{6}$ F. FRNTIĆ, Od igara okruglim predmetom do nogometa, u: F. KRAMER (ur.), Hrvatski nogometni savez. 80. obljetnica, Zagreb, 1992., 20. 


\section{Nogomet u Kraljevini Jugoslaviji u ozračju političkih sukoba Hrvata i Srba}

Nakon osnivanja Kraljevine SHS-a 1. prosinca 1918. godine, već pet dana poslije u Zagrebu su izbile velike demonstracije protiv srpske kraljevske dinastije Karađorđevića i nove države. Tada je intervenirala vojska novouspostavljene države i počela je pucati po demonstrantima kojima se pridružio i dio domobrana koji su pobjegli s oružjem, a među njima je bio i nogometaš HAŠK-a Emil Perška. Vojska je tada zapucala na demostrante i ubila trinaest ljudi, dok je sedamnaest bilo ranjeno. ${ }^{7} \mathrm{E}$. Perška zbog straha od novih jugoslavenskih vlasti otišao je u Beč gdje je igrao za klub Wiener AC (WAC), međutim ubrzo je uprava Građanskoga došla po njega u Beč obećavši mu zaštitu od progona novoga režima te je 1919. godine potpisao ugovor s Građanskim. ${ }^{8}$

Završetkom Prvoga svjetskoga rata pokreće se inicijativa da se Nogometna sekcija Hrvatskog športskog saveza proglasi za samostalnu nogometnu organizaciju i preraste u Hrvatski nogometni savez. Osnivačka skupština na kojoj je trebalo osnovati Hrvatski nogometni savez održana je u Zagrebu 14. travnja 1919. godine. ${ }^{9} \mathrm{Među}-$ tim skupštini su nazočili uz delegate iz Hrvatske i predstavnici iz drugih područja nove države. Nakon rasprave prevladalo je mišljenje da bi bilo svrhovitije osnovati nogometnu organizaciju nove države Srba, Hrvata i Slovenaca. U Zagrebu, kao najjačem sportskom centru u Kraljevini SHS-u, 14. travnja 1919. godine osnovan je Jugoslavenski nogometni savez (JNS) i to je bio jedan od prvih sportskih saveza u novostvorenoj zajednici Južnih Slavena. Time je utemeljen Jugoslavenski nogometni savez, umjesto obnavljanja rada Nogometne sekcije Hrvatskog športskog saveza koji je prestao s radom. Nogometni savez nosio je ime Jugoslavenski, iako je službeni naziv nove države od osnutka 1. prosinca 1918. godine bio Kraljevstvo, odnosno Kraljevina Srba, Hrvata i Slovenaca, a tek je 3. listopada 1929. godine ime promijenjeno u Kraljevina Jugoslavija. Prvi predsjednik JNS-a bio je zagrebački pravnik i nekadašnji vratar HAŠK-a Hinko Würth..$^{10}$

Prema nekim mišljenjima Srbi su tada pristajali na sve što su im predlagali čelni ljudi središnje kuće jugoslavenskoga nogometa u Zagrebu. Tako je primjerice predsjednik SK Velika Srbija Danilo Stojanović nakon uvjeravanja predsjednika JNS-a H. Würtha

${ }^{7}$ O tom događaju vidi: H. MATKOVIĆ, Povijest Jugoslavije 1918. - 1991., Zagreb, 2003., 84.

${ }^{8}$ D. KOVAČIĆ, Hrvatski nogomet u doba cara, kralja, poglavnika i maršala, 49.

${ }^{9}$ U knjizi Sto godina nogometa u Hrvatskoj1880. - 1980. (uredili F. FRNTIĆ i D. HRIPKO), Zagreb, 1983., kao datum osnivačke skupštine JNS-a naveden je 15. travnja 1919.

${ }^{10}$ Z. MORNAR, Zablude lažna jedinstva 1919. - 1941., u: F. KRAMER (ur.), Hrvatski nogometni savez, 26. 
da ime Velika Srbija nije prikladno, jer svi trebaju »stremiti jugoslavenskoj zajednici«, promijenio ime beogradskoga kluba u prosincu 1919. godine u SK Jugoslavija. ${ }^{11}$

Iz Beograda Hrvati su optuživani da su lansirali tezu da su Srbi netalentirani za nogomet, da su više ratnici gubitnici te da su zato odlučili da se u prvom državnom prvenstvu 1923. godine završna utakmica može održati samo u Zagrebu te da sudci ne budu iz Beograda jer su neiskusni i nedovoljno educirani. U nogometu se stvarao animozitet, i u Beogradu i u Zagrebu željeli su dokazati da su najjače nogometno središte u novoj državi. Važnost nogometa uviđali su i političari, tako je Stjepan Radić poslije govora pred 10000 ljudi u Gospiću u listopadu 1924. godine razgovarajući sa sportskim dužnosnicima rekao: »Svaki čestiti Hrvat mora da se izvježba u engleskom tipu nogometa kako bi Hrvati mogli dati nogomet svima koji bi nepravedno htjeli upravljati Hrvatskom. ${ }^{12}$

Stvaranje Kraljevine Srba, Hrvata i Slovenaca bilo je odmah obilježeno borbom za prevlast Hrvata i Srba i međusobnim nepovjerenjem i na političkom i na sportskom polju. Naime za vrijeme dok je Hrvatska bila još u sastavu Austro-Ugarske u Zagrebu je, kako sam naveo, održana utakmica između HAŠK-a i reprezentacije Srbije na kojoj je bio izražen osjećaj povezanosti Hrvata i Srba. Međutim stvaranjem zajedničke države na površinu je ubrzo izbio međusobni animozitet i nepovjerenje. Može se navesti mnogo primjera međusobnoga nepovjerenja Hrvata i Srba u nogometu u tom razdoblju. Primjerice kada je splitski Hajduk 1927. godine vodio u Beogradu protiv BSK-a 3 : 0 deset minuta prije kraja utakmice, mnogi na klupi Hajduka počeli su se veseliti. Tada je legendarni splitski trener Luka Kaliterna rekao: »Ljudi, budite oprezni, nemate vi pojma šta sve Srbi mogu učinit u deset minuta. ${ }^{13}$

Diktatura kralja Aleksandra Karađorđevića, uvedena 6. siječnja 1929. godine, izazvala je još veće političke napetosti između Hrvata i Srba. Srpska politička elita željela je uvesti centralizirani državni sustav, oštro se protiveći ideji federalizacije koju je zahtijevala većina hrvatskih političkih vođa. Naime glavna odrednica unutarnje politike kralja Aleksandara Karađorđevića bila je integralno jugoslavenstvo i unitarizam. Radi centralizacije u glavni grad države Beograd premještane su državne institucije, pa je i premještanje nogometnoga saveza bilo dio toga procesa. ${ }^{14}$

Na redovnoj skupštini JNS-a održanoj 16. ožujka 1930. godine u Zagrebu nazočili su delegati iz Zagreba, Osijeka, Splita, Ljubljane, Sarajeva, Beograda, Subotice i

\footnotetext{
${ }^{11}$ A. MIHAJLOVIĆ, Istorija fudbala u Srbiji, (6) »Hrvati vode reprezentaciju «. Dostupno na: https:www.novosti.rs/dodatni-sadrzaj/clanci-Hrvati-vode-reprezentaciju (29. 3. 2020.).

${ }^{12}$ Radićev govor u Gospiću, u: Novo doba, 21. X. 1924., 8.

${ }^{13}$ M. GARBER, Hajduk u sto i jednoj priči, 248.

${ }^{14}$ D. KOVAČIĆ, Hrvatski nogomet u doba cara, kralja, poglavnika i maršala, 53.
} 
Skoplja. Na skupštini se odmah prešlo na raspravu o promjeni članka 1. saveznih pravila o sjedištu saveza is 213 glasova delegata donesena je odluka da se JNS preseli u Beograd, a tamo je premješten i zbor nogometnih sudaca. ${ }^{15}$

Naime, prema tadašnjim pravilima, klub član JNS-a nije morao na skupštinu poslati svoga delegata. Manji registrirani klubovi davali su svoje punomoći predstavnicima većih klubova za koje su vjerovali da će ih bolje zastupati. Svaka punomoć na spomenutoj skupštini značila je jedan glas pa su u to vrijeme pojedini delegati skupštine raspolagali s nekoliko glasova na temelju punomoći klubova. Takav sustav bio je odlučujući pri donošenju odluka jer je jedan delegat mogao imati desetke glasova. Tako je jedan delegat iz Zagreba, prezimena Smoljan, kad se raspravljalo o preseljenju sjedišta saveza, raspolagao s ukupno 26 punomoći sa svoga područja. Međutim te su punomoći na još nerasvijetljen način nestale noć prije sjednice, tako da se na skupštini nisu mogle predočiti. Kasnije se ispostavilo da je upravo nedostatak tih 26 punomoći bio odlučujući za odluku o preseljenju Jugoslavenskoga nogometnoga saveza iz Zagreba u Beograd. Pri glasovanju za novo vodstvo JNS-a većina delegata zagrebačkoga, splitskoga i osječkoga podsaveza napustila je skupštinu te je novo vodstvo izabrano aklamacijom. ${ }^{16}$

Borba oko ostanka, odnosno premještanja saveza između hrvatskih i srpskih nogometnih predstavnika, prema pisanju beogradske Politike toliko se »izopaćila da tu više čovek nije mogao sagledati kraj nerazumnoj i nesportskoj borbi $\ll^{17}$.

Predstavnici dotadašnjega vodstva JNS-a primili su 17. ožujka 1930. godine obavijest od redarstva da odmah prenesu poslovne zadatke novoizabranom vodstvu, što su i učinili dan kasnije. U Beogradu je 22. ožujka 1930. održana prva sjednica JNS-a na kojoj je poslije opširne rasprave odbijena primjedba Zagrebačkoga podsaveza da je Savez premješten u Beograd po nuždi, a ne pravno. ${ }^{18}$ Takva, zapravo politička odluka naišla je na proteste iz Hrvatske, što je imalo za posljedicu da Hrvati nisu htjeli nastupati za reprezentaciju koja je 1930. nastupila na prvom SP-u u Urugvaju. Naime hrvatska javnost bila je revoltirana, devetorica hrvatskih nogometaša s popisa za SP u Urugvaju odbila je igrati za reprezentaciju, a mjesto izbornika jugoslavenske reprezentacije napustio je i dr. Ante Pandaković, a za izbornika nogometne reprezentacije imenovan je arhitekt iz Beograda Boško Simonović. ${ }^{19}$

\footnotetext{
${ }^{15}$ Z. MORNAR, Zablude lažna jedinstva 1919. - 1941., 29.

${ }^{16}$ F. FRNTIĆ, D. HRIPKO (ur.), Sto godina nogometa u Hrvatskoj, 26.

${ }^{17} \mathrm{O}$ povezanosti nogometa i politike u jugoslavenskom društvu vidi: R. MILLS, Nogomet i politika u Jugoslaviji. Sport, nacionalizam i država, Zagreb, 2019.

${ }^{18}$ Z. MORNAR, Zablude lažna jedinstva 1919 - 1941., 29.

${ }^{19}$ D. KOVAČIĆ, Hrvatski nogomet u doba cara, kralja, poglavnika i maršala, 54.
} 


\section{Stvaranje Banovine Hrvatske i borba za ravnopravne odnose u nogometu}

Tročlano Namjesništvo na čelu s knezom Pavlom koje je poslije atentata i ubojstva kralja Aleksandra 1934. godine u Marseillu upravljalo državom uime malodobnoga kralja Petra II. željelo je riješiti tzv. hrvatsko pitanje i postići sporazum s Vladkom Mačekom, vođom Hrvatske seljačke stranke (HSS). U tako stvorenom političkom ozračju, koje se odrazilo i na sport, događale se su promjene i u sportu, odnosno nogometu koji je u Kraljevini SHS-u, odnosno Jugoslaviji, bio obilježen centralizacijom i protežiranjem beogradskih klubova. ${ }^{20}$

Na redovnoj skupštini JNS-a 29. i 30. siječnja 1939. godine u Beogradu Zagrebački nogometni podsavez na prijedlog Gradanskoga pokrenuo je pitanje reorganizacije nogometa osnivanjem nacionalnih saveza, što je naišlo na veliki otpor srpske strane koja je predstavnike hrvatskih klubova iz zagrebačkoga, splitskoga i osječkoga podsaveza nazvala izdajicama, a prijetilo se i policijom i zatvorom. U tako stvorenom ozračju predstavnik Hajduka Ivo Šuste izišao je za govornicu i pozvao 50-ak hrvatskih delegata da napuste skupštinu i tada su predstavnici klubova iz Zagreba, Splita, Osijeka, ali i iz nekih klubova i iz drugih krajeva, demonstrativno napustili skupštinu. ${ }^{21} \mathrm{U}$ sljedećim mjesecima donesena je rezolucija $\mathrm{O}$ samostalnosti $\mathrm{hr}$ vatskog sporta te o načelima reorganizacije, a 14. svibnja 1939. godine u Zagrebu održana je osnivačka skupština Hrvatske športske sloge (HŠS) kojoj je nazočilo 217 delegata klubova s područja zagrebačkoga, splitskoga i osječkoga podsaveza te pojedini delegati s područja banjalučkoga i sarajevskoga podsaveza. HŠS je bila središnja organizacija svih hrvatskih sportskih i tjelovježbenih saveza. Naime hrvatski političari željeli su i sportom promovirati težnju za većom autonomijom i cjelovitošću hrvatskih zemalja. ${ }^{22}$

U nogometu je cilj bio okupiti sve hrvatske nogometne klubove i donijeti zajednički stav prema JNS-u. Donesen je stav da ni jedan igrač hrvatskih klubova ne će nastupati za reprezentaciju Jugoslavije dok se ne reorganizira JNS te se odmah krenulo u osnivanje Hrvatske nogometne lige. JNS je na sjednici 11. srpnja 1939. donio uvjetovano rješenje o isključenju hrvatskih klubova iz svoga članstva ako ne budu sudjelovali u jedinstvenoj ligi. Pregovori su nastavljeni 17. srpnja i poslije višesatne rasprave hrvatska strana nije odustajala od svojih ciljeva, pa je sljedećega dana JNS izvršio rješenje od 11. srpnja i isključio hrvatske klubove iz svoga članstva. Ubrzo poslije te odluke JNS-a, 6. kolovoza 1939. Hrvatska športska sloga na

\footnotetext{
${ }^{20}$ Z. MORNAR, Zablude lažna jedinstva 1919. - 1941., 29.

${ }^{21}$ D. KOVAČIĆ, Hrvatski nogomet u doba cara, kralja, poglavnika i maršala, 87.

${ }^{22}$ Z. MORNAR, Zablude lažna jedinstva 1919. - 1941., 35.
} 
skupštini osniva kao svoju podorganizaciju Hrvatski nogometni savez, a za prvoga predsjednika izabran je dr. Ivo Kraljević. ${ }^{23}$

U Ljubljani je osnovan Slovenski nogometni savez čiji su članovi bili nogometna društva i klubovi s područja Dravske banovine. U takvim novonastalim okolnostima osnovan je i Srpski loptački savez čiji su članovi bili i Borovo i sarajevska Slavija. Istodobno je u Beogradu osnovan Vrhovni nogometni savez Kraljevine Jugoslavije. $^{24}$

Nakon osnutka Banovine Hrvatske HNS je nastojao da se hrvatski nogomet afirmira i na međunarodnoj razini. Naime stvaranje Banovine Hrvatske i reorganizacija sporta omogućili su hrvatskoj nogometnoj reprezentaciji međunarodne prijateljske susrete koji su pokazali da »hrvatski sportaši ništa drugo ne traže, već jednakost i pravednost u sportu, da su Hrvati dostojni partneri politički mnogo većih i moćnijih naroda «. Opisanom reorganizacijom hrvatski, srpski i slovenski nogometni savezi dobili su pravo održavanja prijateljskih nogometnih utakmica. Nogometna reprezentacija Hrvatske odigrala je prvu međunarodnu prijateljsku utakmicu u Zagrebu 2. travnja 1940. na igralištu Građanskoga u Koturaškoj ulici protiv reprezentacije Švicarske i pobijedila rezultatom $4: 0$. Prije prvoga nastupa hrvatske reprezentacije igrači Hrvatske koji su nastupili u crveno-bijelo-plavim dresovima položili su zavjet »na ruke predsjednika Hrvatske športske sloge g. senatora dra. Krnjevića ${ }^{25}$.

O prvoj utakmici i pobjedi reprezentacije Hrvatske pisala je i beogradska Politika, što su prenijele i zagrebačke Ilustrovane sportske novosti:

>Glavna zasluga za ovaj veliki uspjeh hrvatskih nogometaša pripada zagrebačkom Građanskom, čiji su igrači sačinjavali ekipu Hrvatske. Njihov podvig je velik i značajan. Hrvatska reprezentacija doprinijela je ovom lijepom pobjedom ojačanju našeg sportskog ugleda u inostranstvu izvanredno mnogo, dodala je dosadanjim uspjesima našeg nogometa još jedan koji će za vječita vremena ostati. Ova pobjeda ostat će upisana u našoj sportskoj historiji kao jedan od najvećih uspjeha našeg nogometa, kojim će se ponositi i današnje i sve buduće sportske nogometne generacije. $\ll^{26}$

${ }^{23}$ Isto.

${ }^{24}$ F. FRNTIĆ, D. HRIPKO (ur.), Sto godina nogometa u Hrvatskoj, 26.

${ }^{25}$ Izabrani nogometaši Hrvatske u svom prvom sjajnom naletu pobjeđuju mlitave Švicarce 4:0, u: Novosti, 3. 4. 1940., 16.

${ }^{26}$ Naše i švicarske ocjene o igri Hrvatska-Švicarska 4:0, u: Ilustrovane sportske novosti, 9. 4. 1940. Usp. D. KOVAČIĆ, Hrvatski nogomet u doba cara, kralja, poglavnika i maršala, 94. 
Hrvatska nogometna reprezentacija pobijedila je Švicarsku i u uzvratnoj utakmici 21. travnja 1941. godine u Bernu rezultatom $1: 0 .{ }^{27}$ Te pobjede nogometne reprezentacije u Hrvatskoj su pripisivane političkoj reorganizaciji koja se odrazila i na odnose u nogometu u jugoslavenskoj državi te se isticalo da će od tih promjena velikih koristi imati $\gg$ zajednički Football $\ll{ }^{28}$

Prilikom međudržavne utakmice između Hrvatske i Mađarske u Budimpešti organizatori utakmice umjesto hrvatske izvjesili su srbijansku zastavu. U tisku su predstavnici hrvatske nogometne reprezentacije optuženi da nisu poduzeli odgovarajuće korake zbog toga događaja. HNS je o tom događaju izdao obavijest u kojoj se navodilo da su predstavnici hrvatske nogometne reprezentacije odmah, još za vrijeme utakmice, poduzeli korake kod Mađara da se ispravi pogrješka. Međutim Mađari su se ispričali dodajući da im hrvatska državna zastava nije poznata i da bi pred masom publike tijekom utakmice bilo nezgodno mijenjanje zastave s visokih jarbola. Predstavnici HNS-a nisu se zadovoljili takvim odgovorom Mađara pa su službeno obavijestili HŠS i vlasti Banovine Hrvatske o tom slučaju tražeći istragu i opravdanje takvoga događaja protivno međunarodnim propisima i običajima. Utakmica je završila pobjedom reprezentacije Mađarske $1: 0{ }^{29}$

U prosincu 1940. godine odigrana je uzvratna utakmica između reprezentacije $\mathrm{Hr}-$ vatske i Mađarske u Zagrebu i završila je neriješenim rezultatom $1: 1 .{ }^{30}$

\section{Hrvatski nogomet i klubovi u socijalističkoj Jugoslaviji}

Uspostavom Nezavisne Države Hrvatske željelo se organizirati nogomet na novim načelima i »očistiti ga od balkanskih običaja «. U nogometnoj ligi Nezavisne Države Hrvatske sudjelovali su uz klubove iz Zagreba, Osijeka, Borova, Varaždina i klubovi iz Sarajeva, Banje Luke, Mostara i Zemuna, ali je bila okrnjena neigranjem splitskoga Hajduka jer su Rimskim ugovorima o razgraničenju, potpisanim 18. svibnja 1941., Talijani okupirali gotovo cijelu Dalmaciju, velike dijelove Hrvatskoga primorja i dio Gorskoga kotara. Nakon što je Hajduk odbio igrati u talijanskoj nogometnoj ligi, čelni ljudi splitskoga kluba isto su učinili i dvije godine kasnije kada su nakon kapitulacije Italije 8. rujna 1943. godine i uspostave vlasti Nezavisne Države Hrvatske u Splitu i Dalmaciji odbili sudjelovati u prvenstvu. Razlog je bio u

\footnotetext{
${ }^{27}$ I u Bernu su pobijedili Hrvati. Vrlo nadmoćni u igri pobijedili su švicarske izabranike samo s 1:0, u: Novosti, 22. 4. 1940., 8.; Šuprina, Kokotović, Glaser i Jazbec su oduševili Švicarce, koji mogu biti osobito zadovoljni sa 0:1, u: Novosti, 22. 4. 1940., 8.

${ }^{28}$ I u Bernu su pobijedili Hrvati, 8.

${ }^{29}$ Naši međunarodni reprezentativni susreti, u: F. KRAMER (ur.), Hrvatski nogometni savez, 306.

${ }^{30}$ Isto.
} 
kompromitiranosti vlasti Nezavisne Države Hrvatske prijašnjom trgovinom hrvatskim područjima, napose dalmatinskom obalom. ${ }^{31}$

Najuspješniji klubovi u Nezavisnoj Državi Hrvatskoj koji su rezultatski djelovali i bili uspješni i u nogometnim prvenstvima Kraljevine SHS-a, odnosno Jugoslavije nakon završetka Drugoga svjetskoga rata odlukom i postupkom komunističkih vlasti, uz paljenje klupskih arhiva, bili su raspušteni. Uspostavom komunističke vlasti u Jugoslaviji svi prijeratni nazivi sportskih organizacija bili su promijenjeni, ali je splitski Hajduk zbog prelaska partizanima tijekom Drugoga svjetskoga rata zadržao ime. Komunističke vlasti zamislile su da Hajduk kao klub partizanske tradicije promiče ideju jugoslavenstva, slično kao i beogradski Partizan. ${ }^{32}$

U Beograd su »vojnim dekretom《završetkom Drugoga svjetskoga rata došli ponajbolji zagrebački nogometaši (Stjepan Bobek, Zlatko Čajkovski, Franjo Glaser, Miroslav Brozović, Franjo Šoštarić, Florijan Matekalo), ali i istaknuti nogometaši iz drugih sredina, primjerice Kiril Simonovski iz Skoplja. Pred istaknute nogometaše koji su igrali u klubovima NDH-a postavljan je »ultimatum «. Ako odbiju prelazak u Partizan, služit će vojni rok u »nekoj pustopoljini« ili će ih sudski progoniti, tako da je tih godina u beogradskom Partizanu igralo više igrača rođenih u Zagrebu nego što ih je bilo u Dinamu. ${ }^{33}$

U nogometnoj ligi socijalističke Jugoslavije od samoga početka hrvatski klubovi osjećali su se manje ravnopravnim u odnosu na srpske klubove. Primjerice navijači Hajduka bili su nezadovoljni odnosom nogometne administracije iz čelne kuće jugoslavenskoga nogometa u Beogradu prema splitskom klubu. Tako su se u predzadnjem kolu nogometnoga prvenstva Jugoslavije u Splitu sastali NK Hajduk i FK Crvena zvezda 29. listopada 1950. godine. Oba kluba imala su isti broj bodova i splitskom klubu za naslov trebala je pobjeda. Na spomenutu utakmicu došla je i organzirana navijačka skupina splitskih studenata iz Zagreba koja je dan ranije osnovala Torcidu, najstariju navijačku skupinu na prostoru bivše Jugoslavije. Student Žarko Štiglić popeo se na balkon i pročitao »osmrtnicu « koja je, prema zapisniku Politbiroa Centralnog komiteta Komunističke partije Hrvatske (CK KPH) koji je zasjedao 18. prosinca 1950. godine, »vrijeđala igrače Zvezde i bila napisana šovinističkom žaokom « ${ }^{34}$. Nadalje se u izvještaju navodi da su u Zagrebu Torcidu dočekali prijatelji i navijači Dinama »među kojima je bilo i proustaških tipova « i da su u upravi Hajduka sve to znali. $U$ »elektriziranoj « atmosferi na utakmici NK-a

${ }^{31}$ D. KOVAČIĆ, Hrvatski nogomet u doba cara, kralja, poglavnika i maršala, 149-154.

${ }^{32}$ D. LALIĆ, Nogomet i politika. Povijest i suvremenost meduodnosa u Hrvatskoj, Zagreb, 2018., 130.

${ }^{33}$ Z. MAGDIĆ, Legende zagrebačkog nogometa, 384.

${ }^{34}$ M. GARBER, Hajduk u sto i jednoj priči, 147. 
Hajduka i FK-a Crvene zvezde 1950. bilo je grubosti koje su vrhunac doživjele u »šakačkom obračunu « kapetana Hajduka Frane Matošića i nogometaša beogradskoga kluba Branka Stankovića. Kapetan Hajduka izjavio je pred partijskom komisijom: $\gg$ Žao mi je što Stankovića nisam udario i jače $\ll$, i dodao da istrage ne bi ni bilo da Zvezda nije izgubila utakmicu $(2: 1){ }^{35}$

Nogometaš Dinama Krešimir Pukšec navodi da je u tom prvenstvu utakmica između Dinama i Crvene zvezde u Zagrebu bila utakmica koju su nogometaši zagrebačkoga kluba igrali za $\gg$ bratski $<$ Hajduk kojemu je poraz beogradskoga kluba otvarao vrata naslova prvaka. Pukšec je postigao zgoditak kojim je Dinamo pobijedio $\mathrm{Cr}$ venu zvezdu te je tako Hajduk postao prvakom Jugoslavije. Prema njegovu iskazu Maksimir je bio na nogama, skakao od radosti, »osjetili smo da smo Hrvati ${ }^{36}$.

Na utakmicama hrvatskih i srpskih klubova događali su se i nacionalistički ispadi navijača, tako su na utakmici u Zagrebu $\gg$ drukeri « NK-a Dinama vikali igračima BSK-a (Beogradskoga sportskoga kluba) »četnici «. Naime formiranje nogometnoga kluba BSK-a, koji je djelovao i u razdoblju između dvaju svjetskih ratova i uz zagrebački Građanski bio najuspješniji klub, izazvalo je kod dijela navijača $D i$ nama akciju za obnavljanje Građanskoga. Ta akcija opravdavala se kao reakcija na ponovno osnivanje BSK-a i tada se među navijačima zagrebačkoga kluba pričalo da je maršal Josip Broz Tito u jednom razgovoru kazao da se pogriješilo kada se poslije završetka Drugoga svjetskoga rata nije ponovno oformio Građanski, nego je osnovan Dinamo. ${ }^{37}$ Naime BSK je 1945. ukinut, kao i drugi predratni beogradski klubovi, a ukidanje se opravdalo njihovim igranjem za vrijeme Drugoga svjetskoga rata. Umjesto BSK-a u Beogradu je 1945. osnovan FK Metalac koji je zadržao boje dresova predratnoga BSK-a, a i grb je bio sličnoga oblika. Klub Metalac igrao je u poratnim prvenstvima Jugoslavije, a na izvanrednoj skupštini kluba 22. srpnja 1950. donesena je odluka da se klubu vrati ime BSK, iako je postojala sumnja da će komunistička vlast dopustiti povratak toga imena. Međutim Vladimir Dedijer, tadašnji visoki politički dužnosnik i predratni navijač BSK-a, rekao je da je BSK »baš lepo ime « i da ne vidi u tome problem. Klub je pod imenom BSK nastupao do 26. studenoga 1957., kada je dospio u lošu financijsku situaciju i poslije sjedinjenja s nižerazrednom TSK-om Šumadijom, u kojoj je navodno bilo »geneksovaca-operativaca $\mathrm{UDBE}_{\ll}$, mijenja ime u OFK Beograd. ${ }^{38}$

\footnotetext{
${ }^{35}$ Isto, 148.

${ }^{36}$ Z. MAGDIĆ, Legende zagrebačkog nogometa, 289.

${ }^{37}$ B. VOJNOVIĆ (ur.), Zapisnici Politbiroa Centralnoga komiteta Komunističke partije Hrvatske 1945. - 1992., II, Zagreb, 2005., 595.

${ }^{38}$ D. KOVAČIĆ, Hrvatski nogomet u doba cara, kralja, poglavnika i maršala, 187.
} 
Prema iskazu Bogdana Cuvaja, koji je obavljao visoke dužnosti u nogometu i u Kraljevini Jugoslaviji i za vrijeme NDH-a, 1950-ih je tadašnji predsjednik NSJ-a Rato Dugonjić pozvao u Beograd predstavnike zagrebačkih klubova i obavjestio ih da je moguća obnova starih imena zagrebačkih nogometnih klubova i istaknuo: $\gg \mathrm{Da}$, vi možete ponovo umjesto Dinama, Metalca uzeti imena HAŠK-a ili Concordie. Mi nećemo imati ništa protiv (...). Ali jedno, više ne smijete i ne možete vratiti, ime Građanskog. « Prema riječima B. Cuvaja predstavnici zagrebačkih klubova tada su zaključili: »Ak nemre Građanski onda ne bumo vraćali ni HAŠK ni Concordiu ni druge... $\ll^{39}$

Potkraj 1952. godine u Beogradu su Hajdukovi navijači, pripadnici Torcide, nazivani ustašama, fašistima i srboubojicama. U Zagrebu 9. prosinca 1952. poslije utakmice NK-a Dinama i FK-a Crvene zvezde, za Kup maršala Tita, velika skupina navijača proslavila je pobjedu pjevajući hrvatsku himnu Lijepa naša i domoljubne pjesme Marjane, Marjane, Još Hrvatska ni propala, Vila Velebita i druge. Pred spomenikom kralju Tomislavu uzvikavali su »do-lje ka-pe «, uz skidanje kape, ali su vlasti to razumjele kao »dolje $\mathrm{KP} \ll$. Spomenuti uzvik točno je razumjela i ondašnja milicija koja je uhitila 46 navijača, od kojih se devetorici sudilo. ${ }^{40}$

\section{Borba za ravnopravne odnose u nogometu}

Krajem 1960-ih i početkom 1970-ih socijalističke republike težile su emancipaciji od saveznoga državnoga partijskoga centra te da same upravljaju svim područjima društvenoga života. S druge strane dogmatsko-unitarističko-centralističke snage inkriminirale su republički partikularizam kao najveću opasnost za socijalizam i jedinstvo Jugoslavije. U SR Hrvatskoj stvorila se svijest i klima o nužnosti lomova starih struktura te se nastojalo postići da se republike sve više osamostaljuju. Naime u Hrvatskoj je vladalo nezadovoljstvo nedovoljnim gospodarskim razvitkom i stanjem međunacionalnih odnosa u Jugoslaviji. Nadglasavanje u gospodarskim pitanjima ( $5: 1$ na štetu Hrvatske) bilo je shvaćeno kao prijetnja ravnopravnosti Hrvatske $\mathrm{u}$ jugoslavenskoj zajednici. ${ }^{41}$

Tada se u SR Hrvatskoj razvila velika kampanja za likvidaciju, kako se govorilo, otuđenih središta gospodarske moći i za čiste račune u Jugoslaviji. Takve tendencije pojavile su se i u NS Hrvatske, gdje se postavilo pitanje definiranja odnosa unutar

${ }^{39}$ Z. MAGDIĆ, Legende zagrebačkog nogometa, 338.

${ }^{40}$ Z. RADELIĆ, Hrvatska u Jugoslaviji 1945. - 1991., od zajedništva do razlaza, Zagreb, 2006., 266. Usp. Hrvatski državni arhiv, (HDA), Rukopisna ostavština (RO) dr. Ivo Politeo, k. 15, Miletić i dr. 1953. N. KISIĆ-KOLANOVIĆ, Ivo Politeo. Povijest, intelektualci, odvjetništvo 1887. - 1956., Zagreb, 2015., 240-266.

${ }^{41}$ O tome vidi: Z. RADELIĆ, Hrvatska u Jugoslaviji 1945. - 1991., od zajedništva do razlaza, 329-434. 
NSJ-a, odnosno formiranja njegovih tijela, te se težilo da o politici u nogometu ne odlučuje NSJ iz Beograda, nego da o tome odlučuju republike i pokrajine. ${ }^{42}$

Naime, kako je prethodno istaknuto, pitanje ravnopravnosti postavili su predstavnici NS-a Hrvatske pod utjecajem društvenih strujanja u Hrvatskoj koje će kulminirati MASPOK-om, odnosno hrvatskim proljećem. U tom vremenu 1971. godine smijenjeni su i neki članovi rukovodstva NK-a Dinama Otto Hofman, Ante Todorić, Ivica Prodan te još neki članovi uprave. Povod smjeni bila je kanadsko-američka turneja Dinama na kojoj je igrao i s klubovima $\gg$ hrvatske emigracije «. Međutim vjerojatno je stvarni povod smjeni bilo obilježavanje 25. obljetnice NK-a Dinama 1970. godine te je na toj proslavi službeno prihvaćen znak Dinama koji je kreirao O. Hofman i koji su igrači na dresovima nosili već 1969. godine. Naime Hofman je 1969. iznio prijedlog koji su prihvatili i ostali članovi uprave, da se na dresove Dinama stavi novi grb koji je zapravo bio okrugli hrvatski grb s crvenim i bijelim poljima, što je tada bila smiona odluka te su je visoki partijski krugovi ocjenjivali nacionalističkom. ${ }^{43}$

Poslije sjednice u Karađorđevu krajem 1971. godine započeo je obračun s liberalnim snagama unutar SKJ-a, a prvo se na udaru našlo vodstvo CK-a SKH-a. U takvim političkim okolnostima predsjednik Dinama Dragutin Božić podnio je ostavku na čelo kluba. ${ }^{44}$

Nacionalističkim ispadima uslijed nastalih političkih strujanja i događaja u SR Hrvatskoj ocijenjeni su i događaji u svezi s utakmicom Hajduk - OFK Beograd odigranom u Splitu 27. rujna 1970. godine. ${ }^{45}$ Naime utakmica je prekinuta pri rezultatu $2: 2$ jer se glavni sudac Pavle Ristić u jednom trenutku uhvatio za glavu i kao pokošen srušio na zemlju. $U$ prvi trenutak nitko nije znao što se dogodilo glavnom sudcu koji je prevezen u bolnicu. Neki su se rugali tom »misterioznom «slučaju, kazavši da je sudca možda udario šišmiš, pa je tako i nazvana ta afera. Kasnije se saznalo da je sudac Ristić pogođen komadom betona odlomljenim od tribine Staroga placa. ${ }^{46}$ Poslije utakmice koja je registrirana $0: 3$ na splitskoj rivi završili su u moru automobili s beogradskim registracijskim pločicama, navijači su skandirali $\gg$ Hajduk-Dinamo-Savka-Tripalo «. Međutim nad sudionicima izgreda nije doš-

\footnotetext{
${ }^{42}$ Srbija (SR) Arhiv Jugoslavije (AJ), fond-734-Fudbalski savez Jugoslavije, (FSJ), Problem reprezentovanosti u forumima, K-29.

${ }^{43}$ D. KOVAČIĆ, Hrvatski nogomet u doba cara, kralja, poglavnika i maršala, 255.

${ }^{44}$ D. KOVAČIĆ, Intervju s Perom Zlatarom, Zagreb, 14. 5. 2016., (neobjavljeno). P. Zlatar istaknuti novinar i publicist. Usp. D. KOVAČIĆ, Hrvatski nogomet u doba cara, kralja, poglavnika i maršala, 256.

${ }^{45}$ SR-AJ-683, Zajednica fudbalskih klubova Prve savezne lige, Predmeti spornih utakmica, fasc. 42.

${ }^{46}$ Isto. Više o tome dostupno na: https://hajduk.hr/povijest/1971-1980 (31. 3. 2020.).
} 
lo do veće represije vjerojatno i zbog ozračja nadolazećega hrvatskoga proljeća 1971. godine. Na kraju je utakmica registrirana rezultatom koji je postignut na terenu $2: 2$, ali »slučaj šišmiš « izvlačio se svaki put kada bi splitski klub bio upleten u neki do kraja nerazjašnjen incident. ${ }^{47}$

Treba istaknuti da su se u tom razdoblju i u tadašnjoj SR Srbiji pojavili političari liberalno-tehnokratske orijentacije na čelu s Markom Nikezićem, predsjednikom, i Latinkom Perović, sekretaricom Saveza komunista Srbije. Nakon njihova odlaska $\mathrm{s}$ istaknutih položaja i u drugim socijalističkim republikama bilo je sučeljavanja u političkim vodstvima, koncepcijske razlike postojale su i među partijskim čelnicima u SR Bosni i Hercegovini, SR Sloveniji i SR Makedoniji. S političkih dužnosti smijenjeni su i nogometni funkcionari, odnosno dužnosnici koji su pripadali tim krugovima. ${ }^{48}$

\section{Navijački sukobi kao najava ratnih događanja}

U Jugoslaviji smrću Josipa Broza Tita 1980. godine nastupa ekonomska, društvena i politička kriza koja će trajati do raspada jugoslavenske federacije 1991. godine. Poslije Titove smrti, a poglavito sredinom 1980-ih usporedno s političkom i gospodarskom krizom na nogometnim stadionima počeli su se pojavljivati navijači s republičkim zastavama umjesto klupskih i koji su pjevali razne nacionalističke pjesme uz skandiranje pojedinih političkih slogana. ${ }^{49}$ Od Titove smrti do sredine 1980-ih nasilničko ponašanje navijača i uzvikivanje šovinističih slogana bili su odraz popuštanja ideološke »stege « te sve većih političkih i gospodarskih prijepora u javnom životu. Krajem 1980-ih navijači su postali i aktivnim sukreatorima javnoga mnijenja, uzvikivali su političke slogane izravno okupljenima na stadionima te posredstvom radija i televizije. Nekoliko dana poslije održavanja prvih višestranačkih izbora u Hrvatskoj 13. svibnja 1990. godine dogodili su se na stadionu u Maksimiru dobro znani navijački izgredi zbog kojih nije odigrana utakmica između Dinama i Crvene zvezde. Uoči utakmice počeo je masovni sukob nekoliko tisuća navijača Dinama i oko 2500 navijača beogradskoga kluba koje je je predvodio međunarodni kriminalac sa zaštitom jugoslavenske tajne službe Željko Ražnatović Arkan, koji je sudjelovao i u kasnijim ratnim događajima i mnogobrojnim zločinima kao zapovjednik srpske paravojne organizacije Tigrovi. Kapetan Dinama Zvonimir Boban

\footnotetext{
${ }^{47}$ D. KOVAČIĆ, Hrvatski nogomet u doba cara, kralja, poglavnika i maršala, 256.

${ }^{48}$ O političkim odnosima u tom vremenu vidi: H. MATKOVIĆ, Povijest Jugoslavije, 363-374., Z. RADELIĆ, Hrvatska u Jugoslaviji 1945. - 1991., od zajedništva do razlaza, 329-434.

${ }^{49}$ O politizaciji navijačkih skupina u Jugoslaviji tijekom 1980-ih vidi: H. RASCHKE, Jugoslavien in der Kurve. Repräsentationen des sozialistischen Jugoslawiens als politischer Bestandteil der Fußballfankultur im (post-) jugoslawischen Raum, u: Südosteuropäsche Hefte 4(1), 66-86.
} 
nasrnuo je na pripadnika ondašnje milicije koji je napadao jednoga Dinamova navijača. Zbog toga događaja NSJ kaznio je Bobana sa šest mjeseci zabrane igranja, a protiv njega podignuta je optužnica Javnog pravobranilaštva jer je fizički napad na službenu osobu, milicajca, bio kažnjivo djelo. ${ }^{50}$ Prema ocjeni britanskoga pisca i novinara Jamesa Montaguea neodigrana utakmica Dinamo - Crvena zvezda jedna je od pet utakmica koje su promijenile svijet. ${ }^{51}$

Nekoliko tjedana poslije nemilih događaja, 3. lipnja 1990. godine u Zagrebu na maksimirskom stadionu odigrana je utakmica između reprezentacija Jugoslavije i Nizozemske. Bila je to prijateljska utakmica u sklopu priprema za SP u nogometu 1990. godine. Zagrebačka publika, ogorčena političkom situacijom u državi, izviždala je jugoslavensku himnu »Hej Slaveni «. Prema nekim mišljenjima, taj dan na stadionu Maksimir Jugoslavija se raspala. ${ }^{52}$

Kao bunt protiv velikosrpske politike na utakmici Hajduk - Partizan, odigranoj 26. rujna 1990. na splitskom Poljudu, pripadnici Torcide su s tribina istrčali na igralište prekinuvši utakmicu i sa službenoga jarbola skinuli su i zapalili službenu jugoslavensku zastavu. Tako zapaljenu ponovno su je vratili na službeni jarbol uz odobravanje publike na stadionu. ${ }^{53}$

\section{Zaključak}

Početkom 20. stoljeća na području Hrvatske organiziraju se prvi nogometni klubovi, čije je osnivanje bilo motivirano i političkim razlozima, odnosno nezadovoljstvom prilikama i položajem hrvatskoga naroda u Austro-Ugarskoj Monarhiji. Osnivanje zagrebačkoga Građanskoga i splitskoga Hajduka bilo je uz ostale čimbenike uvjetovano takvim razlozima.

Poslije završetka Prvoga svjetskoga rata u novoosnovanoj Kraljevini Srba, Hrvata i Slovenaca (SHS), odnosno Kraljevini Jugoslaviji, naziv koji je nosila od 1929. godine nogomet je izazivao veliku pozornost javnosti. Zbog snažne političke upotrebljivosti i njegove prijemčivosti za izražavanje etničkih i drugih identiteta te za promicanje političkih ideja i pokreta na posredan način, nogomet je u Kraljevini SHS-u/Jugoslaviji često bio i pozornica za izražavanje političkih sporova i podjela. Hrvatski klubovi bili su nezadovoljni svojim položajem i odnosom najviših nogometnih vlasti koje su premjestile i sjedište JNS-a iz Zagreba u Beograd. Nogomet u Kraljevini SHS-u/Jugoslaviji bio je obilježen sve većim prijeporima istaknutih

\footnotetext{
${ }^{50}$ D. LALIĆ, Nogomet i politika, 172.

${ }^{51}$ O tome vidi: J. MONTAGUE, When Friday Comes: Football in the War Zone, Edinburgh, 2008.

${ }^{52}$ D. KOVAČIĆ, Hrvatski nogomet u doba cara, kralja, poglavnika i maršala, 323.

${ }^{53}$ D. LALIĆ, Nogomet i politika, 164.
} 
klubova iz Hrvatske i Srbije koji su pratili političke sukobe Hrvata i Srba na državnoj razini.

Nakon uspostave komunističkoga režima u Jugoslaviji usporedno s izgradnjom i razvojem socijalističkih odnosa razvijali su se i odnosi u nogometu koji je postao sport $\mathrm{s}$ najvećim brojem članova, a usto privlačio je najviše publike na utakmice. $\mathrm{U}$ tom razdoblju povremeno su se pojavljivali i nacionalistički ispadi navijača na nogometnim igralištima. Predstavnici i navijači hrvatskih klubova osjećali su da su u neravnopravnom položaju u odnosu na klubove iz Srbije te se postavljalo pitanje ravnopravnije zastupljenosti u nogometnim forumima.

Poslije Titove smrti, a poglavito sredinom 1980-ih usporedno s političkom i gospodarskom krizom na nogometnim stadionima počeli su se pojavljivati navijači s republičkim zastavama umjesto klupskih i koji su pjevali razne nacionalističke pjesme uz skandiranje pojedinih političkih slogana. Zaoštravanje političkih odnosa između političkih rukovodstava republika i pokrajina postalo je detonatorom sukoba navijačkih skupina koji su od verbalnih prerastali u fizičke obračune i koji nisu prestali sve do raspada Jugoslavije te su zapravo bili samo predigra krvavim ratnim sukobima. 


\title{
FOOTBALL AS A MEANS OF NATIONAL IDENTIFICATION OF CROATS IN THE KINGDOM OF SERBS, CROATS AND SLOVENES / YUGOSLAVIA AND SOCIALIST YUGOSLAVIA
}

\author{
Davor KOVAČIĆ*
}

Summary: It is a mistake to think that football is just a physical movement, a rough coercion of an opponent, because it is often more than a game. Football is a contemporary social phenomenon, and the state of football is often an indicator of the state of society and politics. In the Croatian and generally South Slavic areas, football was the most popular sport from the very beginning, and it attracted the largest number of spectators and aroused great public interest. Football is never just football, it is always politicized and it reflects relations in society in general, and in a way it is an X-ray of everything that is going on in society. The article shows how football in the Kingdom of Serbs Croats and Slovenes / Yugoslavia and in socialist Yugoslavia was a means of expressing Croatian ethnical and national identity due to political disputes and divisions.

Keywords: Croats, Serbs, Croatia, Yugoslavia, politics, football, football clubs.

* Davor Kovačić, Ph. D., Croatian Institute of History, Zagreb, Opatička ulica 10, 10000 Zagreb, Croatia,dkovacic@isp.hr 